\title{
PENANGANAN PROBLEMATIKA MASYARAKAT DI MASA PANDEMI COVID-19
}

\section{HANDLING COMMUNITY PROBLEMS DURING THE COVID-19 PANDEMIC}

\author{
Wahibatul Maghfuroh $^{1)}$, Budi Hariyanto ${ }^{2)}$ Tedy Herlambang ${ }^{3)}$ \\ 1,2,3 Universitas Panca Marga Probolinggo \\ ${ }^{1}$ Email: wahibatulmaghfuroh@upm.ac.id
}

\begin{abstract}
Abstrak: Kegiatan ini bertujuan untuk membentuk kebijakan dan mengedukasi masyarakat untuk melakukan pencegahan Covid-19 dengan tetap menerapkan dan mematuhi protokol kesehatan yaitu dengan menjaga jarak (physical distancing), mencuci tangan, memakai masker dan tetap menjaga imunitas tubuh dengan mengonsumsi vitamin. Kegiatan pengabdian kepada masyarakat akan memberi peran penting untuk mendukung program pemerintah dalam menangani Covid-19. Kegiatan ini melibatkan masyarakat sekitar empat kecamatan yaitu Pakuniran, Paiton, Besuk dan Kotaanyar. Sehingga memerlukan edukasi tentang pencegahan Covid-19 untuk meminimalisir penyebaran Covid-19. Program yang akan diadakan di empat kecamatan yaitu pembagian masker dan handsanitizer sebagai bentuk sosialisasi sehingga masyarakat memiliki kesadaran pentingnya menerapkan protokol kesehatan yang berguna untuk memutus rantai penularan Covid-19. Salah satu hal yang dapat memicu penyebaran Covid-19 yaitu kurangnya kesadaran dan kepedulian masyarakat terkait pentingnya menerapkan protokol kesehatan dan kurangnya edukasi terhadap pencegahan virus Covid-19. Sehingga Pengabdian mahasiswa Universitas Panca Marga dalam kegiatan KKN tahun 2021 ini berfokus pada upaya penanganan dampak pandemi Covid $-19 \mathrm{di}$ masyarakat dan penyuluhan tentang pernikahan sirri di desa bocor kecamatan kotaanyar. Pandemi Covid-19 berdampak sangat luas pada kehidupan sosial dan ekonomi masyarakat: ribuan orang berpotensi terjatuh ke dalam kemiskinan, kekurangan gizi, banyak usaha kecil terancam gulung tikar, serta anak-anak usia sekolah yang drop-out. Pengabdian masyarakat dilakukan dengan meluncurkan program-program kegiatan mencangkup aspek-aspek bidang yang terdampak antara lain bidang pendidikan, UMKM dan kesehatan.
\end{abstract}

Kata Kunci: KKN, Covid-19

Abstract: This activity aims to form policies and educate the public to prevent Covid-19 by still applying and complying with health protocols, namely by maintaining distance (physical distancing), washing hands, wearing masks and maintaining immunity by taking vitamins. Community service activities will provide an important role to support government programs in dealing with Covid19. This activity involves the community around four sub-districts namely 
pakuniran, paiton, besuk and kotaanyar. So it requires education about the prevention of Covid-19 to minimize the spread of Covid-19. The program will be held in four sub-districts, namely the distribution of masks and handsanitizers as a form of socialization so that the public has awareness of the importance of implementing health protocols that are useful to break the chain of transmission of Covid-19. One of the things that can trigger the spread of Covid-19 is the lack of awareness and public concern regarding the importance of implementing health protocols and lack of education on the prevention of the Covid-19 virus. . So that the service of Panca Marga University students in KKN activities in 2021 focuses on efforts to deal with the impact of the Covid-19 pandemic in the community and counseling about sirri marriage in the village of bocor kotaanyar subdistrict. The Covid-19 pandemic has had a far-reaching impact on people's social and economic lives: thousands of people could potentially fall into poverty, malnutrition, many small businesses are at risk of going out of business, as well as school-age children dropping out. Community service is carried out by launching programs to cover aspects of the affected fields, including education, MSMEs and health.

Keywords : Real work college, Covid-19

\section{PENDAHULUAN}

Masyarakat di kecamatan pakuniran, paiton, besuk dan kotaanyar berprofesi sebagai pedagang, petani, nelayan dan lain-lain. Pada saat Covid-19 melanda, banyak harga produk yang mengalami kenaikan dan penurunan. Pembatasan jam buka toko-toko dan tempat belanja menyebabkan tingkat pendapatan menurun hingga 50\%, hal ini kemudian juga berimbas pada UKM, UMKM, usaha makanan dan usaha kecil lainnya. Pembatasan jam buka tidak hanya diberlakukan untuk usaha besar saja dan pembatasan tersebut dapat mengakibatkan penurunan penjualan dan permintaan dari konsumen akibat himbauan untuk dirumah saja dan untuk menghindari banyaknya kerumunan yang dapat menyebabkan penyebaran Covid-19 yang semakin luas.

Sebagaimana daerah lain, selama pandemi Covid-19 ini pelajar dan mahasiswa di empat kecamatan juga melakukan proses belajar secara daring sesuai dengan instruksi Kementerian Pendidikan dan Kebudayaan untuk menyelenggarakan pembelajaran jarak jauh dan menyarankan para peserta didik untuk belajar dari rumah masing-masing. Meskipun pembelajaran ini kurang efektif karena banyak mengalami kendala seperti tidak memiliki ponsel pintar, kualitas layanan internet yang buruk, biaya langganan paket data internet yang 
memberatkan masyarakat, kendala finansial dan kendala lainnya. Kebijakan ini diharapkan dapat mengurangi penyebaran Covid-19 dengan pembelajaran di rumah saja, namun masih banyak siswa yang tidak menggunakan masker saat pembelajaran bersama di rumah.

Coronavirus disease 19 (Covid-19) adalah sebuah penyakit klinis yang disebabkan oleh virus corona baru yang disebut dengan SARS-CoV-2, yang mana telah melanda negara-negara yang ada di dunia yang membuatnya dikategorikan sebagai sebuah pandemi oleh Organisasi Kesehatan Dunia (WHO) tertanggal pada 11 Maret 2020 (WHO, 2020). Pandemi Covid-19 ini merupakan wabah ketiga yang telah tercatat, dengan sindrom pernapasan akut pada tahun 2002 (SARS, SARS-CoV-1 atau SARS-CoV) dan epidemi sindrom pernapasan di Timur Tengah (MERS atau MERS-CoV) pada tahun 2012 sebelumnya (Jack \& Vasso, 2021). Tercatat pula bahwa antara tahun 2002 hingga 2004 virus SARS-CoV-1 (atau SARS-CoV) menyebabkan 774 kematian dari 8.096 kasus yang dilaporkan, dengan tingkat kematian kasus (CFR) sebesar 11\% (Moira \& Rui-Heng, 2003) dan untuk virus MERS (MERS-CoV) ini memiliki CFR yang lebih tinggi yaitu lebih besar dari 35\% dengan angka kematian sebanyak 850 dari 2400 kasus yang dilaporkan (WHO, 2019). Sedangkan pada kasus COVID-19 sendiri, pada saat penulisan yang tertanggal pada 16 Agustus 2021, dilaporkan telah tercatat sebanyak 206.762.789 kasus di seluruh dunia dengan angka kasus kematian mencapai 4.354.321 kasus (WHO, 2020) dan dengan perkiraan CFR berkisar berada diantara $2 \%$ hingga $4 \%$, namun dapat pula hingga menyentuh perkiraan paling tinggi $25 \%$ pada negara-negara tertentu yang memiliki sistem kesehatan yang rendah (Gabrielle dkk, 2020).

Teruntuk Negara Indonesia sendiri, penyebaran virus SARS-CoV-2 ini juga telah banyak menimbulkan kasus serta korban. Terhitung pada tanggal 16 Agustus 2021, terdapat 3.854.354 kasus yang terlaporkan terkonfirmasi positif terinfeksi Covid-19 dengan angka kasus kematian yang mencapai angka 117.588 kasus (WHO, 2020). Salah satu cara pemerintah usaha penanggulangan penyebaran Covid-19 yang tersebar luas serta menekan angka kasus terkonfirmasi terinfeksi ialah dengan menetapkan regulasi pembatasan interaksi masyarakat seperti 
Pembatasan Sosial Berskala Besar (PSBB) yang tertuang dalam Peraturan Pemerintah Republik Indonesia Nomor 21 Tahun 2020 tentang pembatasan sosial berskala besar dalam rangka percepatan penanganan corona virus disease 2019 (Covid-19) yang mana pada dapat dilihat pada pasal 4 ayat 1 bahwa pembatasan ini merupakan pembatasan total karena meliputi poin-poin peliburan sekolah dan tempat kerja, pembatasan kegiatan keagamaan dan/atau pembatasan kegiatan di tempat atau fasilitas umum (RI, 2020) serta regulasi Pemberlakuan Pembatasan Kegiatan Masyarakat (PPKM) secara berkala di berbagai daerah di Indonesia, terhitung pada waktu penulisan, dari tanggal 06 Januari 2021 yang ditetapkan dalam Instruksi Menteri Dalam Negeri Nomor 01 Tahun 2021 tentang Pemberlakuan Pembatasan Kegiatan Untuk Pengendalian Penyebaran Corona Virus Disease 2019 (Covid-19) hingga tanggal 16 Agustus 2021 yang ditetapkan dalam Instruksi Menteri Dalam Negeri Nomor 34 Tahun 2021 Tentang Pemberlakuan Pembatasan Kegiatan Masyarakat Level 4, Level 3, dan Level 2 Corona Virus Disease 2019 Di Wilayah Jawa dan Bali.

Namun, penekanan persebaran virus Covid-19 dengan melakukan penerapan regulasi pembatasan kegiatan masyarakat yang diambil oleh pemerintah, selain berdampak kepada sasaran utama yaitu persebaran virus Covid-19, juga berdampak pada kehidupan masyarakat. Dalam hasil riset yang dilakukan oleh Rindam \& Islamul (2020) ditemukan bahwa pemberlakuan pembatasan kegiatan masyarakat membuat menurunnya pendapatan masyarakat dan menyebabkan turunnya daya beli masyarakat, yang mana artiannya ialah masyarakat tidak mampu membeli bahan kebutuhan sehari-hari. Hal tersebut tentu juga akan mempengaruhi sektor UMKM yang ada, yang mana para pengusaha kecil akan kesulitan mendapatkan pelanggan sebab menurunnya angka pelanggan.

Selain itu juga dalam aspek pendidikan penerapan pelaksanaan kegiatan secara dalam jaringan (daring) yang dikarenakan oleh regulasi pembatasan kegiatan masyarakat juga memberikan dampak yang cukup besar. Dari 4.475 mahasiswa yang menjadi responden penelitian yang dilakukan oleh Jagad dan Heru (2021), dominan mengatakan tidak puas terhadap pembelajaran dalam jaringan (daring) (62\%), sangat kurang dalam mendapatkan materi (79\%) dan 
merasa jenuh \& bosan (39\%) (Jagad \& Heru, 2021). Hal tersebut juga sejalan dengan penelitian dari Abdillah (2021) yang dilakukan dengan mengamati siswa kelas X IPA, yang mana dalam hasil penelitian tersebut menunjukkan siswa terlibat aktif terlibat dalam kegiatan komponen kontekstual serta tahapan-tahapan pembelajaran daring hanya sebesar $38 \%$ (Abdillah, 2021). Adapun juga dari sudut pandang tenaga pengajar merasa bahwa pembelajaran yang dilakukan secara langsung tatap muka dirasa lebih efektif dikarenakan pengaplikasian pembelajaran secara daring yang mereka peroleh hanya terfokus kepada pemberian tugas dari rasio dari pemberian materi sendiri sangatlah kecil (Sitti, 2020).

Oleh sebab itu dikarenakan permasalahan-permasalahan yang ada, dalam Pedoman Kuliah Kerja Nyata Tematik tahun 2021 Universitas Panca Marga dijabarkan pelaksanaan pengabdian masyarakat oleh mahasiswa dalam Kuliah Kerja Nyata Universitas Panca Marga tahun 2021 lebih dikhususkan kepada penanggulangan serta pencegahan Covid-19 dengan cara mendukung dan/atau menguatkan program penanggulangan Covid-19 yang dilakukan oleh pemerintah pusat maupun daerah, meningkatkan pertumbuhan ekonomi masyarakat di masa pandemi serta mengedukasi masyarakat akan bahaya sekaligus cara pencegahan Covid-19 (UPM, 2021). Tujuan-tujuan khusus tersebut akan tercerminkan dan menjadi pedoman untuk pembuatan program-program kegiatan yang dilaksanakan selama waktu pelaksanaan kegiatan KKN agar kegiatan akan tepat dapat memberikan manfaat bagi masyarakat terkait (Fitri, 2015).

\section{METODE PELAKSANAAN}

Metode yang di gunakan dalam mengatasi masalah dari yang di paparkan pada bagian pendahuluan adalah sebagai berikut :

1. Diskusi dan Observasi Lapangan Tahap ini dilakukan diskusi dengan kelompok KKN (Kuliah Kerja Nyata) untuk menentukan pogram apa yang akan di selenggarakan selama proses pengabdian berlangsung. Konsep pogram yang awalnya masih bersifat umum kemudian disempurnakan dengan memperhatikan saran, kritik dan masukan dari anggota lain. Sehingga didapatkan solusi yang sesuai dengan kondisi masyarakat. Melakukan 
Observasi Lapangan sendiri di lakukan untuk mengetahui bagaimana lokasi tempat kegiatan nantinya dan apakah Pogram tersebut cocok di gunakan pada wilayah tersebut.

2. Membagi masker dan Video Edukasi terkait Covid-19

Pada tahap ini membagi-bagikan berupa Masker dan Handsanitizer yang akan menjadi pogram Individu Kuliah Kerja Nyata dari kelompok ini. Berikutnya membuat sebuah video edukasi terkait Covid-19 dengan target sasaran adalah masyarakat dan murid sekolah. Tujuan dari pembuatan video edukasi ini adalah Pelaksanakan kegiatan KKN ini terbagi dalam 4 bidang, yaitu, bidang pendidikan, UMKM, kesehatan serta non-profit. Dalam pembagian bidang tersebut kami melaksanakan program kegiatan yang telah disesuaikan dengan masalah dan kondisi masyarakat di empat kecamatan pakuniran, paiton, besuk dan kotaanyar kabupaten Probolinggo.untuk memberi edukasi terkait Covid-19 kepada khalayak luas.

3. Pengeditan dan Penguploadan Video di Sosial Media

Tahap ini merupakan tahap selanjutnya dari pogram kelompok yaitu pengeditan video dan penguploadan video di sosial media. Pengeditan video di lakukan dengan salah satu aplikasi atau software. Lalu setelahnya di lakukan penguploadan video di sosial media dengan tujuan untuk memberi edukasi pada masyarakat terkait Covid-19 dan cara pencegahannya..

4. Pembagian Masker dan Handsanitizer

Pada tahap ini merupakan pelaksanaan pogram individu yaitu pembagian masker dan handsanitizer oleh kelompok. Pembagian masker dan handsanitizer di lakukan pada wilayah masing-masing yang berpusat di empat kecamatan pakuniran, paiton, besuk dan kotaanyar. Target sasaran dari pembagian ini adalah masyarakat sekitar..Partisipasi mitra sangat dibutuhkan dalam pelaksanaan program KKN, berikut akan dijabarkan peran mitra dalam kegiatan ini,

a. Memberi masukan,ide, kritik dan saran terhadap gagasan tim pelaksana.

b. Membantu proses pembuatan masker dan handsanitizer alami. 
c. Mensosialisasikan kegiatan melalui video edukasi terkait Covid-19.

d. Menyiapkan segala sesuatu yang dibutuhkan dalam kegiatan pogram KKN.

e. Berkoordinasi secara aktif dengan tim pelaksana program KKN Setelah pelaksanaan program ini, akan dilakukan evaluasi kegiatan untuk mengetahui kelebihan maupun kekurangan selama kegiatan pogram tersebut berlangsung. Rancangan evaluasi dalam kegiatan $\mathrm{KKN}$ ini ditetapkan untuk mengevaluasi terhadap proses persiapan kegiatan dan pelaksanaan kegiatan. Rincian rancangan evaluasi terhadap kegiatan KKN tersebut disajikan dibawah ini.

5. Penyuluhan tentang pernikahan sirri di desa bucor kecamatan pakuniran, ini adalah kegiatan non profit.

\section{Metode pelaksanaan program kerja}

Bidang pendidikan:

Bimbingan teknis belajar

Bidang UMKM

a. Pembuatan X-banner untuk mempromosikan hasil produk.

b. Melakukan promosi melalui sosial media.

c. Ikut serta dalam produksi pembuatan batik

Bidang kesehatan:

a. Pembagian masker dan handsanitizer

b. Sosialisasi pembuatan handsanitizer alami

Sosialisasi tentang pentingnya menjaga protokol kesehatan di masa pandemic Covid-19

Non profit:

Penyuluhan tentang hukum nikah sirri.

\section{HASIL DAN PEMBAHASAN}

Kuliah Kerja Nyata (KKN) adalah suatu kegiatan intrakulikuler yang memadukan pelaksanaan tri dharma perguruan tinggi (pendidikan, penelitian, dan pengabdian kepada masyarakat) dengan cara memberikan kepada mahasiswa 
pengalaman belajar dan bekerja dalam kegiatan pembangunan masyarakat sebagai wahana penerapan dan pengembangan ilmu dan teknologi yang dilaksanakan diluar kampus dalam waktu mekanisme kerja dan teknologi persyaratan tertentu. Kecamatan pakuniran, paiton, besuk dan kotaanyar kabupaten Probolinggo, Sebagian besar penduduk empat kecamatan tersebut bekerja sebagai pedagang maupun petani. Sebagaimana kebiasaan dan kondisi sosial di lingkungan empat kecamatan, juga merupakan daerah pusat pedesaan. Namun jumlah masyarakat yang tidak mematuhi protokol kesehatan di empat kecamatan yang lumayan banyak membuat kelurahan ini masuk ke dalam salah satu zona merah di Kabupaten Probolinggo.

Dengan kasus ini kelompok KKN Pasukan Anyar melakukan pogram kerja yang berkaitan dengan pencegahan penyebaran Covid-19. Pogram kerja KKN kecamatan pakuniran, paiton, besuk dan kotaanyar sendiri terdiri dari pembuatan video edukasi, pembagian masker dan handsanitizer, penyuluhan. Tujuan dari kegiatan tersebut adalah mengurangi jumlah kasus penyebaran Covid-19 dan pengurangan nikah sirri di kabupaten Probolinggo.

\section{Covid-19 (corona virus disease 2019)}

COVID-19 adalah penyakit menular yang diakibatkan invensi virus corona virus jenis baru. Penyakit ini di ketahui muncul pertama kali di wuhan, Cina pada desember 2019 (WHO, 2020). Covid-19 merupakan penyakit pernafasan akut yang menjadi pandemic global yang di sebabkan oleh Novel Corona Virus atau SAR-Cov-2 (Ellich, 2020).

\section{KKN (Kuliah Kerja Nyata)}

Kuliah Kerja Nyata merupakan program kurikuler wajib bagi seluruh mahasiswa S1, program KKN ini termuat dalam program studi. Kuliah Kerja Nyata ini adalah bentuk pengabdian mahasiswa terhadap masyarakat, dimaa mahasiswa membantuk masyarakat dalam bidang Ekonomi, Pendidikan, dan Kesehatan.

\section{Masyarakat}

Masyarakat adalah kumpulan manusia yang memiliki kemandirian dengan bersama-sama untuk jangka waktu yang lama dan juga mendiami suatu daerah 
atau wilayah. Di mana dalam wilayah tersebut memiliki kebudayaan yang tidak berbeda di dalam kelompok tersebut. Tingkat sosial di dalam masyarakat itu sangat besar di mana masyarakat hidup dengan berdampingan satu dengan yang lainnya.

\section{A. Identifikasi Masalah}

1. Program Bidang Pendidikan

Kurang efektifnya pembelajaran Daring yang dilakukan akibat dampak penyebaran virus Covid-19.

\section{Program Bidang UMKM}
a. Menurunnya permintaan akan produk selama masa pandemi berlangsung.
b. Keterbatasan jangkauan pemasaran.
c. Kurangnya tenaga kerja yang ada.

3. Program Bidang Kesehatan

a. Harga Handsanitizer yang melonjak akibat tingginya permintaan masyarakat akan ketersediaan, yang mana berdampak pada harga Handsanitizer yang tidak dapat dijangkau oleh kalangan masyarakat desa.

b. Kurangnya pemahaman masyarakat desa tentang pentingnya menggunakan masker dan Handsanitizer di masa pandemi saat ini.

\section{Program Bidang Non-Profit}

a. Kurangnya pengetahuan masyarakat tentang dampak yang terjadi pada pernikahan sirri.

b. Kurangnya pengetahuan masyarakat tentang arti penting pernikahan menurut Agama dan berdasarkan Hukum Positif Indonesia.

c. Meningkatnya angka Perselingkuhan dan Poligami di kalangan masyarakat.

\section{B. Solusi Permasalahan}

1. Program Bidang Pendidikan

a. Pendampingan belajar siswa-siswi dilingkungan tempat domisili anggota KKN sehingga bisa membantu pengawasan belajar siswa-siswi tersebut.

b. Edukasi tentang bahaya virus Covid-19 dengan memberikan edukasi 3M (Memakai Masker, Menjaga Jarak dan Mencuci tangan). 
c. Edukasi dengan permainan yang meningkatkan daya konsentrasi dan kekompakan

\section{Program Bidang UMKM}

a. Pendampingan pemasaran digital produk UMKM Batik Tulis Pancor Emas

b. Membantu dalam proses pembuatan batik tulis, mulai dari membuat desain sampai tahap pewarnaan, serta memasarkannya kepada masyarakat yang dibagi dalam 4 kecamatan yaitu Paiton, Besuk, Pakuniran dan Kotaanyar

3. Program Bidang Kesehatan

a. Mengadakan penyuluhan kepada siswa-siswi SMK Mambaul Ulum Paiton tentang cara pembuatan Handsanitizer dari bahan dasar daun sirih untuk mempermudah memperoleh Handsanitizer di masa pandemi saat ini tanpa harus mengeluarkan biaya banyak.

b. Membagikan masker dan Handsanitizer secara gratis kepada masyarakat Desa Bucor Kulon.

\section{Program Bidang Non-Profit}

Mengadakan edukasi Luring Penyuluhan dengan Tema "Perkawinan Sirri menjadi ajang menutupi Perselingkuhan di Masyarakat". Tema ditangkap berdasarkan ketentuan yang telah tertera pada pedoman KKN Tematik 2021 yang dikeluarkan oleh Universitas Panca Marga Probolinggo dengan Tujuan Meminimalisir angka perselingkuhan dan Poligami serta memberikan pengetahuan terkait pentingnya akta Otentik oleh Kantor Urusan Agama.

\section{Rencana Kegiatan}

Tabel 1. Rencana Kegiatan Program Kerja KKN

\begin{tabular}{|c|c|l|l|l|l|}
\hline No & Pelaksanaan & $\begin{array}{c}\text { Bidang } \\
\text { Kegiatan }\end{array}$ & Nama Kegiatan & Tempat & Sasaran \\
\hline 1. & $\begin{array}{c}05 / 08 / 2021- \\
25 / 08 / 2021\end{array}$ & $\begin{array}{l}\text { Bidang } \\
\text { Pendidikan }\end{array}$ & $\begin{array}{l}\text { Kegiatan belajar } \\
\text { mengajar dengan } \\
\text { siswa-siswa yang } \\
\text { tinggal di sekitar } \\
\text { lingkungan rumah. }\end{array}$ & $\begin{array}{l}\text { Desa tempat } \\
\text { kelompok kecil } \\
\text { berdomisili }\end{array}$ & $\begin{array}{l}\text { Siswa-siswi } \\
\text { kelas 1 sampai } \\
\text { 6 Sekolah } \\
\text { Dasar }\end{array}$ \\
\hline
\end{tabular}




\begin{tabular}{|c|c|c|c|c|c|}
\hline 2 & 03/08/2021 & \multirow{3}{*}{$\begin{array}{l}\text { Bidang } \\
\text { UMKM }\end{array}$} & $\begin{array}{l}\text { Perkenalan } \\
\text { sekaligus diskusi } \\
\text { terkait } \\
\text { permasalahan yang } \\
\text { ada di Batik Tulis } \\
\text { Pancor Emas }\end{array}$ & $\begin{array}{l}\text { Sanggar Batik } \\
\text { Tulis Pancor } \\
\text { Emas }\end{array}$ & $\begin{array}{l}\text { Seluruh Tim } \\
\text { KKN Pasukan } \\
\text { Anyar }\end{array}$ \\
\hline 3 & $11 / 08 / 2021$ & & $\begin{array}{l}\text { Membantu dalam } \\
\text { proses pembuatan } \\
\text { batik tulis mulai } \\
\text { dari menggambar } \\
\text { desain sampai } \\
\text { dalam proses } \\
\text { mewarnai }\end{array}$ & $\begin{array}{l}\text { Sanggar Batik } \\
\text { Tulis Pancor } \\
\text { Emas }\end{array}$ & $\begin{array}{l}\text { Seluruh Tim } \\
\text { KKN Pasukan } \\
\text { Anyar }\end{array}$ \\
\hline 4 & $17 / 08 / 2021$ & & $\begin{array}{l}\text { Mempromosikan } \\
\text { kerajinan batik tulis } \\
\text { pancor Emas } \\
\text { dengan } \\
\text { menggunkan x- } \\
\text { Banner yang } \\
\text { dilakukan bersama } \\
\text { seluruh tim KKN } \\
\text { Pasukan Anyar }\end{array}$ & $\begin{array}{l}\text { Pasar Bucor } \\
\text { Kulon }\end{array}$ & $\begin{array}{l}\text { Seluruh } \\
\text { masyarakat di } \\
\text { Desa Bucor } \\
\text { Kulon, } \\
\text { pedagang dan } \\
\text { pembeli yang } \\
\text { ada di pasar }\end{array}$ \\
\hline 5 & 08/08/2021 & $\begin{array}{l}\text { Bidang } \\
\text { Kesehatan }\end{array}$ & $\begin{array}{l}\text { Pembuatan } \\
\text { Handsanitizer }\end{array}$ & $\begin{array}{l}\text { SMK Mambaul } \\
\text { Ulum Paiton }\end{array}$ & $\begin{array}{l}\text { Siswa-siswi } \\
\text { SMK Mambaul } \\
\text { Ulum }\end{array}$ \\
\hline \multicolumn{6}{|c|}{ Program Bidang Non-Profit } \\
\hline \multicolumn{6}{|c|}{$\begin{array}{l}\text { - Persiapan awal dilakukan dengan membentuk tim panitia dari anggota Kelompok KKN } \\
\text { Pasukan Anyar dari Ketua Pelaksana, moderator, MC, dan perangkat lain yang bertugas } \\
\text { dalam acara Penyuluhan Hukum. } \\
\text { Selanjutnya meminta ijin kepada pihak Kepala Desa Bucor Kulon Kecamatan Pakuniran } \\
\text { melalui surat ijin tembusan dari Ketua Koordinator Lapangan Kelompok KKN Pasukan } \\
\text { Anyar, selanjutnya surat tembusan kepada Dekan Fakultas Hukum terkait pemberian ijin } \\
\text { Narasumber sesuai tema bidang penyuluhan, kemudian surat tembusan kepada Kapolsek } \\
\text { Kecamatan Pakuniran untuk mengirimkan Babinkamtibmas Desa bucor Kulon serta } \\
\text { Danramil Kecamatan Pakuniran untuk mengirim Babinsar Desa Bucor Kulon untuk turut } \\
\text { serta dalam acara penyuluhan Hukum. } \\
\text { Selain hal ini, panitia juga menerbitkan Sertifikat bagi Narasumber sekaligus Peserta } \\
\text { Penyuluhan dengan mengetahui Koordinator Lapangan dan Ketua Pelaksana Penyuluhan } \\
\text { Hukum. }\end{array}$} \\
\hline
\end{tabular}




\section{Pelaksanaan}

\section{Program Bidang Pendidikan}

Kegiatan dilaksanakan di beberapa titik desa yang menjadi domisili anggota KKN yang tersebar di 4 kecamatan. Ada enam kelompok yang melakukan kegiatan ini dan dimulai sejak tanggal 5 Agustus 2021 sampai 25 Agustus 2021. Kegiatan ini dilakukan secara tatap muka dengan jumlah terbatas tidak lebih dari 20 siswa dan jumlah di masing-masing kelompok berbeda.

Tim KKN juga melakukan kordinasi dengan guru serta wali kelas dari setiap siswa sehingga terdapat sinergi dan komunikasi yang baik antara siswa, guru dan tim KKN. Selain belajar pelajaran wajib sekolah, setiap siswa akan diajarkan bagaimana menjaga kesehatan, memakai masker dan permainan edukasi untuk meningkatkan keterampilan siswa.

Peralatan yang dibutuhkan selama kegiatan ini adalah :

1) Papan Tulis

2) Spidol

3) Penghapus

4) Smartphone untuk melihat tugas yang diberikan masing-masing guru

5) Buku pedoman siswa atau buku tema siswa SD

6) Masker

\section{Program Bidang UMKM}

Pelaksanaan kegiatan ini dilaksanakan pada hari Selasa 03 Agustus 2021 dengan agenda kegiatan kunjungan pertama ke sanggar batik Pancor Emas, kegiatan selanjutnya dilaksakan pada hari rabu 11 Agustus 2021 dengan agenda kegiatan Tim KKN Pasukan Anyar membantu dari proses pembuatan desain batik sampai dalam proses pewarnaan dan di terakhir adalah mempromosikan batik tulis dari Pancor Emas yang diwakili oleh seluruh kelompok terbatas KKN Pasukan Anyar.

3. Program Bidang Kesehatan

a. Pembuatan Handsanitizer

Pelaksanaan kegiatan ini dilakukan secara luring dan dilaksanakan pada hari Minggu Tanggal 08 Agustus 2021 pukul 08.00-12.00 WIB. 
Prosedur Pelaksanaan :

1) Persiapan bahan-bahan dan alat, audien serta tempat penyuluhan

2) Praktek Kelompok KKN PASUKAN ANYAR dan penjelasan tentang pembuatan Handsanitizer. Adapun tata caranya yaitu sebagai berikut :

a) Memasukkan air ke dalam panci sebanyak $1200 \mathrm{ml}$ dan panaskan.

b) Pisahkan daun sirih dari tangkainya sebanyak 50 gram

c) Memasukkan daun sirih ke dalam air yang mendidih lalu tunggu sampai 10 menit

d) Matikan kompor lalu dinginkan

e) Setelah dingin tambahkan alkohol sebanyak 300ml lalu aduk merata

f) Setelah tercampur rata sering dengan penyaring dan masukkan dalam wadah bersih

g) Lalu dikemas atau dimasukkan ke dalam botol Handsanitizer spray

h) Membagikan hasil pembuatan Handsanitizer tersebut kepada Siswa-siswi SMK Mambaul Ulum.

\section{b. Pembagian Masker Dan Handsanitizer}

Pelaksanaan kegiatan ini yaitu dilaksanakan secara luring pada Selasa 17 Agustus 2021 Pukul 08.00-12.00 WIB di depan pasar Bucor Kulon.

Prosedur Kegiatan :

1) Kelompok KKN menggunakan Handsanitizer terlebih dahulu untuk mensterilkan tangan

2) Handsanitizer dan masker dimasukkan ke dalam plastik klip (packing)

3) Membagikan setiap satu paket masker dan Handsanitizer kepada satu orang sampai selesai

4) Penutup sekaligus evaluasi kegiatan

\section{Program Bidang Non-Profit}

Penyuluhan Hukum diberlangsungkan di Kantor Desa Bucor Kulon secara luring dengan menerapkan protokol kesehatan secara ketat dimulai dari memakai masker, menggunakan handsanitizer bersamaan dengan pengisian daftar hadir, menjaga jarak, selain itu, panitia juga membagi - bagi masker dan handsanitizer kepada peserta Penyuluhan Hukum, Para Undangan yang turut hadir dalam acara, 
serta para pengendara atau pejalan kaki di sekitar depan kantor Desa Bucor Kulon Kecamatan Pakuniran.

a. Penyuluhan Hukum dilaksanakan susuai susunan acara sebagai berikut :

$\begin{array}{ll}\text { 08-00-08.30 WIB } & \text { : Registrasi } \\ 08.30-08.40 \text { WIB } & \text { : Pembukaan } \\ 08.40-08.45 \text { WIB } & \text { : Menyanyi-kan lagu Indonesia Raya } \\ 08.45-08.55 \text { WIB } & \text { : Sambutan Ketua Panitia } \\ 08.55-09.05 \text { WIB } & \text { : Sambutan Kepala Desa Bucor Kulon } \\ 09.05-09.35 \text { WIB } & \text { : Penyajian Materi Penyuluhan } \\ 09.35-10.05 \text { WIB } & \text { : Sesi Tanya Jawab } \\ 10.04-10.15 \text { WIB } & \text { : Penutupan }\end{array}$

b. Peserta Penyuluhan

1) Peserta Penyuluhan beranggotakan 11 orang dari pemuda dan pemudi desa luar, kepala Desa Bucor Kulon, Babinkamtibmas, Babinsar, beserta Kelompok KKN Pasukan Anyar.

2) Narasumber Penyuluhan dilakukan oleh Dosen Pembimbing Lapangan KKN Pasukan Anyar yang juga merupakan Dosen Fakultas Hukum bidang Hukum Perdata konsentrasi Perkawinan.

c. Materi Penyuluhan Hukum :

Materi yang disampaikan oleh narasumber meliputi :

1) Pengertian Nikah Sirri

Nikah sirri yaitu nikah sirri nikah yang dilangsungkan sesuai dengan ketentuan dalam agama islam, tetapi masih bersifat kekeluargaan dan belum tercatat dalam pegawai pencatatan nikah (PPN) sehingga tidak mendapatkan akad nikah. Masyarakat juga sering menyebutnya dengan nikah modin, Nikah kyai atau nikah secara agama.

Ditinjau dari segi sosial nikah sirri dibagi menjadi dua bentuk, yaitu :

a) Pernikahan yang berlangsung secara rahasia antara laki-laki dan perempuan.

b) tanpa kehadiran wali dan saksi sehingga pernikahan ini tidak sah karena tidak.

c) memenuhi syarat dan rukun nikah. 
d) Pernikahan yang berlangsug secara rahasia dengan rukun dan syarat nikah yang lengkap seperti ijab qobul wali dan saksi

Nikah sirri dilakukan pada umumnya karena ada sesuatu yang dirahasiakan, atau karena mengandung suatu masalah. Oleh karena nikah sirri mengandung masalah, maka masalah itu akan berakibat menimpa pada orang yang bersangkutan, termasuk anak-anak yang dilahirkan dari pernikahan sirri. Adapun faktor-faktor penyebab terjadinya nikah sirri di kalangan masyarakat yaitu :

a) Faktor ekonomi, sebagian masyarakat yang memiliki ekonomi menengah kebawah tidak mampu membayar biaya administrasi pencatatan nikah yang mahal, sehingga mendorong masyarakat untuk nikah Sirri

b) Faktor belum cukup umur, sebagian besar orang tua merasa jika anak perempuannya sudah menikah, maka beban keluarga menjadi berkurang meskipun usia anak mereka masih dibawah umur.

c) Faktor ikatan suatu lembaga tertentu, sebagian besar seatu lembaga tertentu tidak mengidzinkan menikah selama waktu tertentu sesuai dengan perjanjian yang telah disepakati.

d) Faktor persepsi yang salah, masih bnyak masyarakat yang beranggapan bahwa nikah sirri sah menurut agama, sedangkan pencatatan hanyalah bagian dari tertib administrasi. Menurut UU 1 tahun 1974 tenteng pasal 2 ayat (1) dan ayat (2) tentang perkawinan

e) Faktor kenakalan remaja, kenakalan remaja merupakan kasus yang hampir dialami oleh sebagian besar remaja. Hal ini terjadi karena hilangnya normanorma dan nilai agama pada remaja saat ini. Sehingga budaya apacaran pun menjadi wajib hukumnya, bahkan sampai mengakibatkan hamil di luar nikah. Kehamilan ini merupakan aib bagi keluarga sehingga oragtuanya harus menikahkan anaknyasecara sirri dengan laki-laki yang menghamilinya dengan alasan menyelamatkan nama baik keluarga

f) Faktor kurangnya pengetahuan dan kesadaran masyarakat tentang pernikahan

g) Faktor sosial. Faktor sosial, yaitu masyarakat sudah terlanjur memberikan stigma negatif kepada setiap orang (laki-laki) yang menikah lebih dari satu 
(berpoligami), maka untuk menghindari stigma negatif tersebut, seseorang tidak mencatatkan pernikahannya kepada lembaga resmi.

h) Sulitnya aturan berpoligami. Untuk dilakukannya pernikahan yang kedua, ketiga dan seterusnya (poligami) ada beberapa syarat yang harus dipenuhi, sesuai dengan syarat poligami yang dijelaskan dalam Pasal 5 Undang-undang No 1 tahun 1974 yaitu harus mendapat izin dan persetujuan dari istri sebelumnya. Hal ini diharapkan dapat memperkecil dilakukannya poligami bagi laki-laki yang telah menikah tanpa alasan tertentu. Dan karena sulit untuk mendapatkan ijin dari istri, maka akhirnya suami melakukan nikah secara diam- diam atau nikah sirri.

i) Masih adanya masyarakat yang melakukan nikah sirri karena tidak ada yang mau mengambil tindakan yang tegas. Dalam Peraturan Pemerintah Nomor 9 Tahun 1975 Tentang Pelaksanaan Undang-undang Nomor 1 Tahun 1974 Tentang Perkawinan Pasal 45.

\section{Dokumentasi Kegiatan}

\section{Program Bidang Pendidikan}

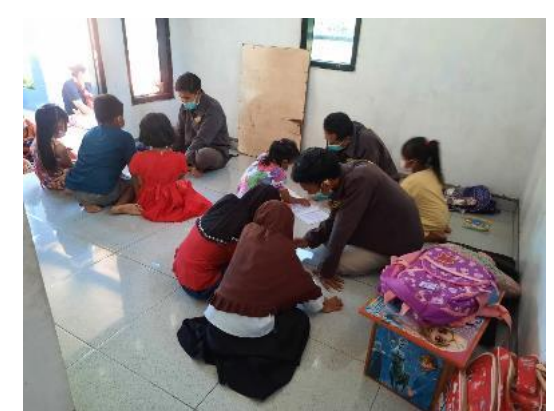

(a)

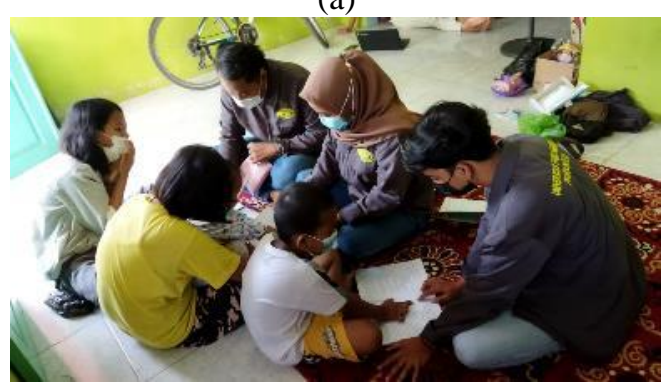

(c)

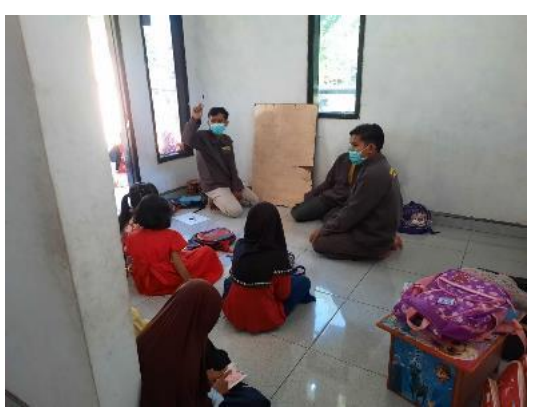

(b)

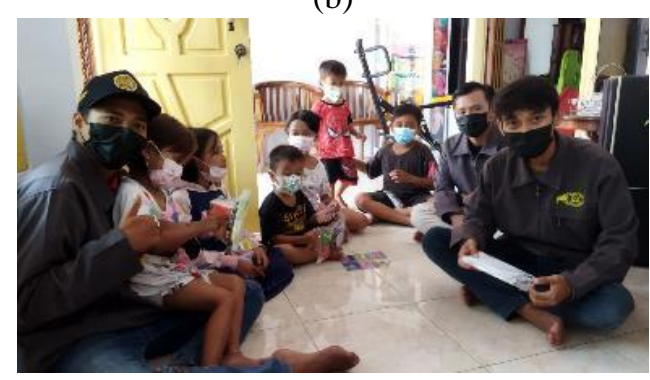

(d) 
INTEGRITAS : Jurnal Pengabdian

Vol 5 No 2 Desember 2021

ISSN 2580- 7978 (cetak) ISSN 2615-0794 (online)

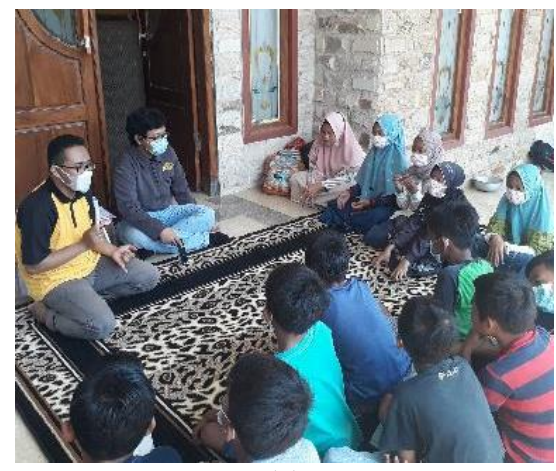

(e)

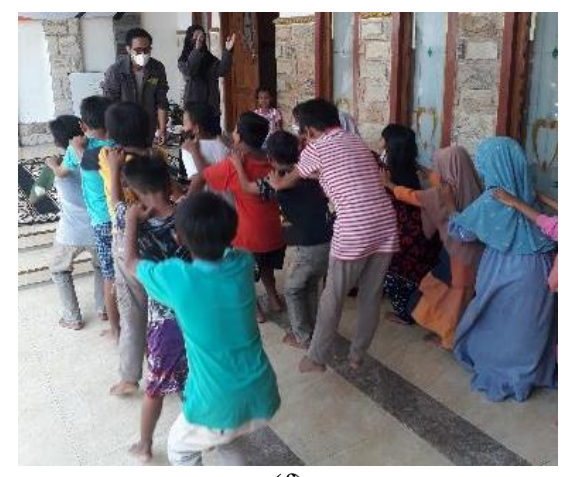

(f)

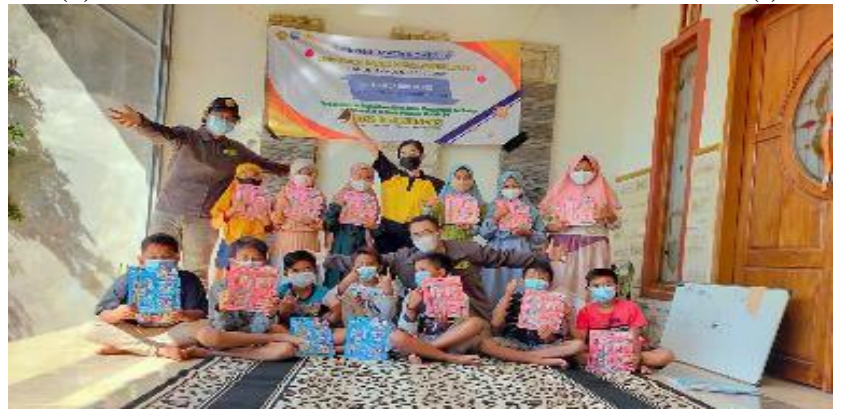

(g)

Gambar 1. Edukasi kepada Siswa Siswi

\section{Program Bidang UMKM}

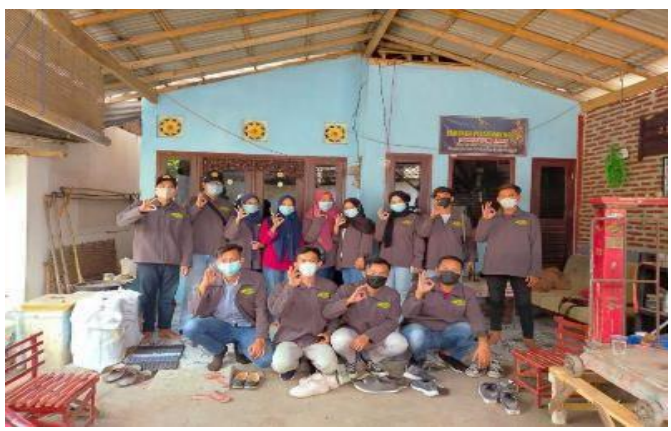

(a)

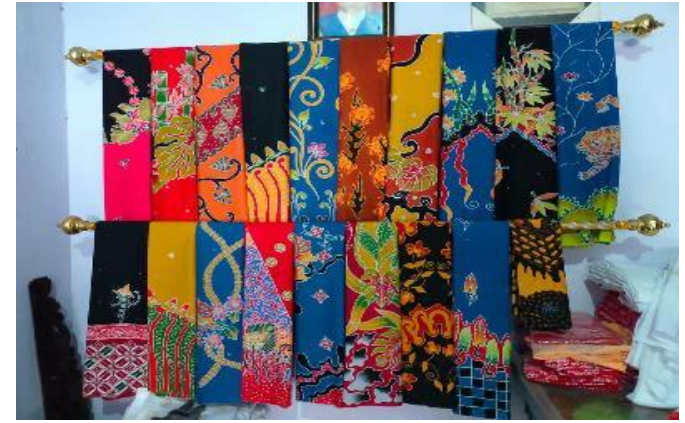

(b)

Gambar 2. Pendampingan Pembuatan dan Pemasaran Batik

\section{Program Bidang Kesehatan}

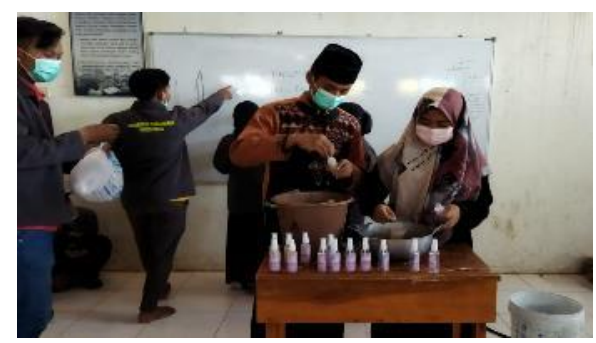

Gambar 1

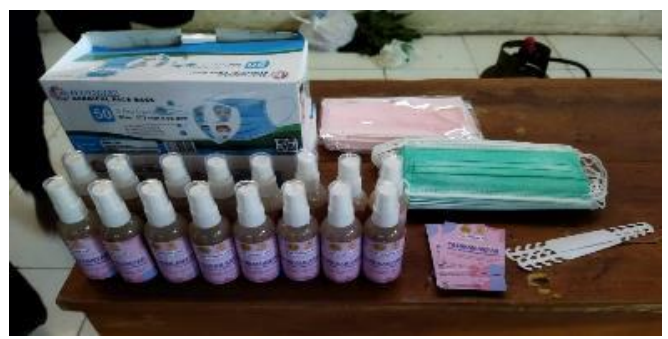

Gambar 2

Gambar 3. Kegiatan Pembuatan Handsanitizer 
INTEGRITAS : Jurnal Pengabdian

Vol 5 No 2 Desember 2021

ISSN 2580 - 7978 (cetak) ISSN 2615 - 0794 (online)

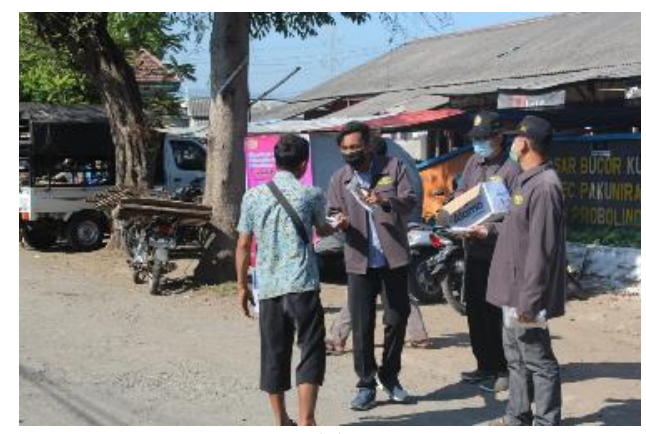

(a)

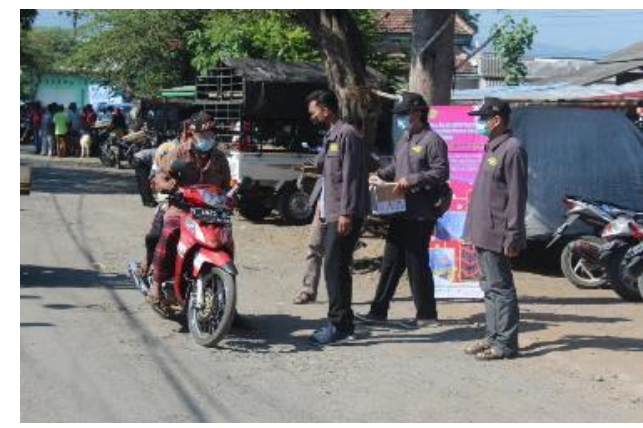

(b)

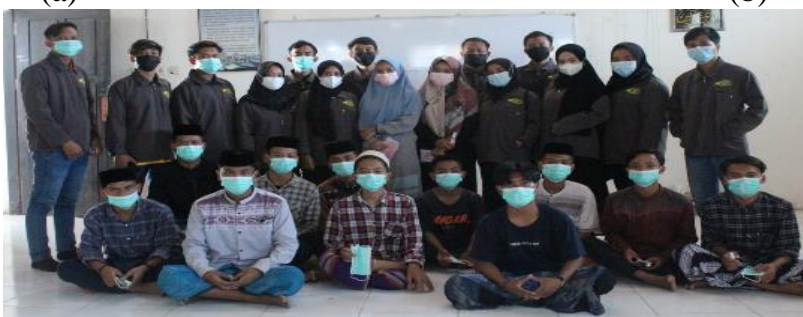

(c)

Gambar 4. Kegiatan Pembagian Masker dan Handsanitizer

\section{Program Bidang Non-Profit}

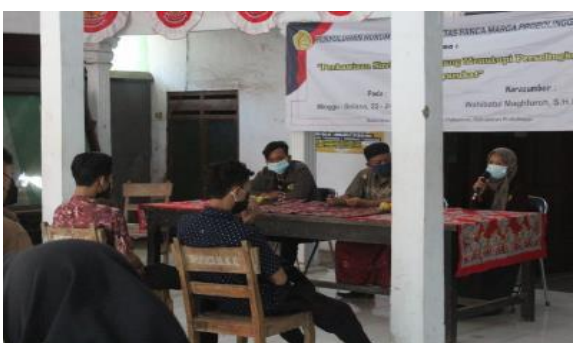

(a)

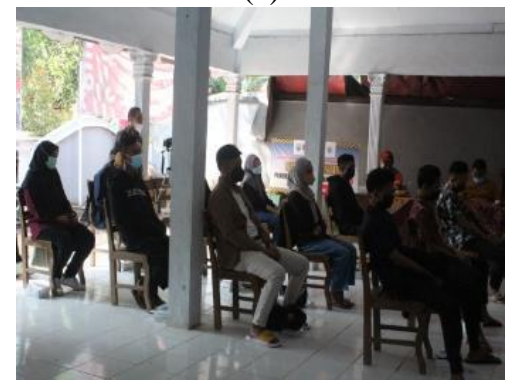

(c)

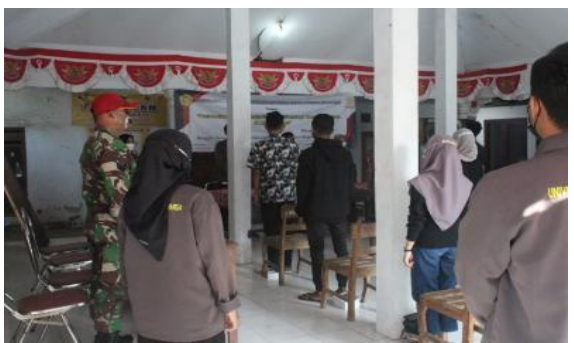

(b)

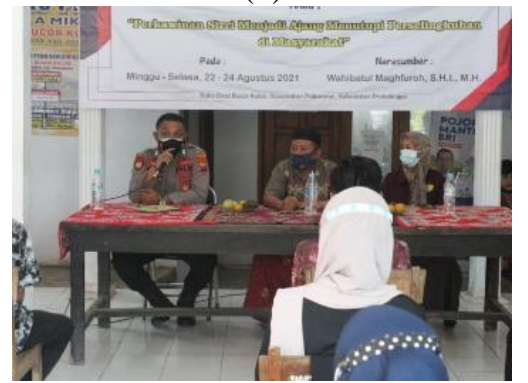

(d)

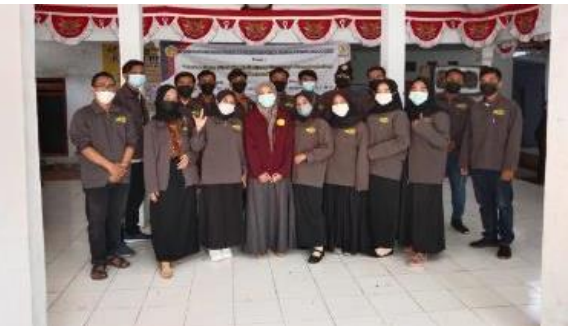

(e)

Gambar 5. Pendampingan Kegiatan Penyuluhan Hukum 


\section{KESIMPULAN}

Selama pandemi Covid-19 berlangsung, terdapat banyak permasalahan yang timbul ditengah-tengah masyarakat. Permasalahan-permasalahan tersebut dapat dikategorikan ke dalam 4 bidang, yaitu permasalahan dalam bidang pendidikan, usaha (UMKM), Kesehatan serta permasalahan dalam bidang sosial (non-profit). Kegiatan KKN Tematik 2021 yang dilaksanakan oleh Universitas Panca Marga mengarahkan Mahasiswa dalam usaha menangani berbagai permasalahan dalam masyarakat tersebut. Hal ini dilaksanakan agar pengabdian mahasiswa kepada masyarakat saat ini dapat benar-benar bermanfaat untuk masyarakat.

Program-program kegiatan yang disusun oleh mahasiswa, sesuai dengan arahan yang ada, dapat berjalan baik dan diterima baik oleh masyarakat maupun mitra terkait yang dipilih. Keberhasilan KKN tematik ini juga ditunjang baik oleh Dosen Pembimbing Lapangan (DPL) melalui bimbingan serta monitoring kegiatan yang sesuai dengan masalah dan kebutuhan yang ada di lapangan.

\section{UCAPAN TERIMA KASIH}

Ucapan terima kasih sampaikan kepada seluruh pihak-pihak mitra terkait desa-desa tempat kegiatan diberlangsungkan serta pihak mitra UMKM dan sekolah yang mana juga telah memberikan izin serta mendukung berlangsungnya kegiatan tim mahasiswa KKN. Tak lupa juga kami mengucapkan rasa terima kasih kami kepada Dosen Pembimbing Lapangan (DPL) yang telah memberikan bimbingan, arahan serta melakukan monitoring kegiatan dari persiapan hingga akhir kegiatan, yang mana juga merupakan alasan seluruh kegiatan kami dapat berlangsung dengan baik dan lancar.

\section{DAFTAR PUSTAKA}

Dewantara, Jagad Aditya., \& $\mathrm{T}$ Heru Nurgiansah. (2021). Efektivitas Pembelajaran Daring di Masa Pandemi COVID 19 Bagi Mahasiswa Universitas PGRI Yogyakarta. Jurnal Basicedu, 5(1), 367-375.

Feehan, Jack, \& Vasso Apostolopoulos. (2021). Is Covid-19 the worst pandemic?. Maturitas, 149, 56-58.

Maulana, Muh Abdillah. (2021). Efektivitas Pembelajaran Daring Siswa Kelas X IPA Terhadap Hasil Belajar Biologi Pada Konsep Biodiversitas. Jurnal Riset dan Inovasi Pembelajaran, 1(1), 85-95. 
Moira Chan-Yeung, dan Rui-Heng Xu. (2003). SARS: epidemiology. Respirology, 8, S9-S14.

Nasruddin, Rindam., \& Islamul Haq. (2020). Pembatasan Sosial Berskala Besar (PSBB) dan Masyarakat Berpenghasilan Rendah. Jurnal Sosial \& Budaya Syar-i, 7(7), 639-648.

Republik Indonesia. Peraturan Pemerintah Republik Indonesia Nomor 21 Tahun 2020 tentang Pembatasan Sosial Berskala Besar Dalam Rangka Percepatan Penanganan Corona Virus Disease 2019 (COVID-19).

Sari, Melani Kartika. (2020). Sosialisasi tentang Pencegahan Covid-19 di Kalangan Siswa Sekolah Dasar di SD Minggiran 2 Kecamatan Papar Kabupaten Kediri. Jurnal Karya Abdi, 4(1), 80-83.

Sorci, Gabrielle, Bruno Faivre dan Serge Morand. (2020). Explaining amongcountry variation in COVID-19 case fatality rate. Scienific Reports, 10(1), $1-11$.

Universitas Panca Marga. Pedoman Kuliah Kerja Nyata Daring Tematik Covid-19 Tahun Akademik 2020/2021. Universitas Panca Marga Probolinggo, 2021.

Wasia, Sitti. (2020). Laporan. FKIP, Administrasi Pendidikan, Universitas Muhammadiyah Kendari Efektivitas Pembelajaran Daring Pada Masa Pandemi COVID-19 Di SAMAN 1 Lambandia., Kendari.

World Health Organisation. (2019). Middle East Respiratory Syndrome Coronavirus (MERS-CoV). Tersedia pada : https://www.who.int /en/news-room/fact-sheets/detail/middle-east-respiratory-syndromecoronavirus-(mers-cov) [16 Agustus 2021].

World Health Organisation. (2020). Coronavirus disease (COVID-19). Tersedia pada : https://www.who.int/emergencies/diseases/novel-coronavirus2019/question-and-answer-hub/q-a-detail/coronavirus-disease-Covid-19 [16 Agustus 2021]

World Health Organisation. (2020). WHO Coronavirus Disease (COVID-19) Dashboard. Tersedia pada : https://covid19.who.int/ [16 Agustus 2021].

World Health Organisation. (2020). WHO Coronavirus Disease (COVID-19) Dashboard. Tersedia pada https://covid19.who.int/region/searo/country/id [16 Agustus 2021]. 